\title{
MARCIN LISAK \\ Formy życia małżeńsko-rodzinnego wśród polskich emigrantów w Dublinie - pomiędzy rozłąką a kohabitacją
}

Mobilność przestrzenna, której popularną formą jest emigracja zagraniczna, staje się codziennym doświadczeniem coraz szerszej części polskiego społeczeństwa. Zjawisko migracji można badać z perspektywy makrostruktur społecznych i makroekonomii. Jednak równie ważnym aspektem „wędrówki ludów” u początku XXI wieku jest znaczenie rodzinne, psychologiczne czy moralnokulturowe, widziane w perspektywie mikrostruktur społecznych. Niniejszy artykuł prezentuje wyniki badań socjologicznych przeprowadzonych wśród polskich emigrantów mieszkających w Dublinie. Analiza wyników dotyczy trzech zasadniczych kwestii. Pierwszą jest różnorodność form życia partnerów, małżonków i rodzin w warunkach emigracyjnych. Drugie zagadnienie stanowi problem rozłąki, rozbicia i łączenia rodzin emigracyjnych. W wyniku badań w młodym pokoleniu polskich katolików ujawniła się szeroka skala życia w kohabitacji. Analiza tego fenomenu jest trzecim tematem niniejszej pracy.

\section{Irlandzkie uwarunkowania}

W ostatnich kilkunastu latach Republika Irlandii przeszła transformację ekonomiczną i demograficzną. $Z$ tradycyjnego kraju emigracji zewnętrznej stała się miejscem docelowym dla imigrantów ${ }^{1}$. W historii irlandzkich wyjazdów za

Marcin L I S A K OP, dr socjologii, professore invitato: Facoltà Scienze Sociali, Pontificia Università S. Tommaso d'Aquino (Angelicum), Roma, e-mail: mlisakop@ dominikanie.pl

${ }^{1}$ Por. P. Share, H. Tove y: M. Corcora n: A Sociology of Ireland. Dublin 2007 s. $152-157$. 
chlebem czynnikiem wypychającym (push factor) była przede wszystkim ekonomia. Po gospodarczym skoku celtyckiego tygrysa na przełomie XX i XXI w., czynnik ekonomiczny stał się motorem przyciągającym (pull factor) migrantów ${ }^{2}$. W dobie kryzysu ekonomicznego, który począwszy od 2008 r. mocno dotknął gospodarkę Irlandii, ponownie odwrócił się kierunek strumienia migracyjnego ${ }^{3}$. Szacunkowe dane demograficzne wskazują, że od 2009 r. mamy do czynienia z ujemnym bilansem migracyjnym ${ }^{4}$. Znowu więcej osób emigruje z Irlandii niż do niej imigruje ${ }^{5}$.

Jedną z najbardziej licznych grup etnicznych wśród imigrantów są Polacy. W porównaniu z kulminacją fali emigracji do Irlandii w latach 2006-2007, w ostatnich dwóch latach napływ migrantów z Polski zdecydowanie się zatrzymał ${ }^{6}$. Nie oznacza to jednak, że migranci masowo wrócili do macierzystego kraju albo przenieśli się z Irlandii w inne miejsce. Brakuje danych empirycznych, które potwierdzałyby obiegowe opinie na temat exodusu większości imigrantów. Wręcz przeciwnie, wyniki kilku fokusowych badań wskazują, że wielu imigrantów pozostaje na wyspie, kierując się strategią przeczekania kryzysu ekonomicznego ${ }^{7}$ oraz strategia ,,zamierzonej nieprzewidywalności” ${ }^{8}$. O kierunku i strategii migracji decydują w przypadku poakcesyjnych przepływów ludności w Europie

${ }^{2}$ Por. M. P h a d r a ig, B. H illi a r: Socio-economic Change in Ireland since the 1980s: The Tiger, the Transnational Corporations and the Peace Dividend. W: B. H i 11 i a r d, M. P h a $\mathrm{d} r \mathrm{a}$ i g (red.): Changing Ireland in International Comparison. Dublin 2007 s. 1-22; A. B a r r e n, A. B e r g i n: The economic contribution of immigrants in Ireland. W: B. F a n n in g (red.): Immigration and social change in the Republic of Ireland. Manchester 2007 s. 63-83.

${ }^{3}$ Por. A. B a r r e t t, I. K e a r n e y, J. Go g g i n: Quarterly Economic Commentary: Spring 2009. Economic and Social Research Institute: Dublin 2009.

${ }^{4}$ Por. E. R u h s, E. Q u i n n: Ireland: from Rapid Immigration to Recession. Centre on Migration, Policy and Society (COMPAS) Oxford University, Economic and Social Research Institute, Dublin, wrzesień 2009 [dostępny w: http://www.migrationinformation.org/Feature/display.cf $\underline{m ? I D=740}(30.10 .2010)]$.

${ }^{5} \mathrm{~W}$ roku 2009 saldo migracyjne (ujemne) szacowane jest na $-7,8$ tys., a w 2010 na $-34,5$ tys. Tymczasem w latach 1996-2008 nieprzerwanie było ono dodatnie - por. Central Statistics Office Ireland: Population and Migration Estimates April 2010. Dublin-Cork 21.09.2010 s. 1-2.

${ }^{6}$ Od stycznia 2000 r. do września 2010 w Irlandii zarejestrowało się (otrzymało numer socjalno-podatkowy) 338.285 polskich obywateli. Przy czym aż $82,4 \%$ procent spośród nich uczyniło to w ciagu 4 lat w okresie maj 2004-kwiecień 2008. W roku 2010 liczba rejestracji Polaków znacznie spadła. Ale i tak w pierwszych 9 miesiącach roku uczyniło to blisko 7 tys. osób, co stanowi najwyższą wartość wśród imigracyjnych nacji. Dane zostały opracowane na podstawie wykazów statystycznych irlandzkiego ministerstwa do spraw społecznych [dostępne w: http://www.welfare.ie/EN/Topics/PPSN/Pages/ppsstat.aspx (30.10.2010)].

${ }^{7}$ Por. T. K ri n g s, A. B o b e k, E. M or i a r t y, J. S a l a m o n s k a, J. W i c k h a m: Migration and Recession: Polish Migrants in Post-Celtic Tiger Ireland. „Sociological Research Online”. R. $2009 \mathrm{nr} 14(2 / 3)$.

${ }^{8}$ Por. S. D r i n k w a t e r, J. E a d e, M. G a r a p i c h: Class and Ethnicity: Polish Migrants in London. Economic and Social Research Council End of Award. Raport z badań. Surrey 2007. 
dalej głównie czynniki ekonomiczne. Jednak w niniejszym artykule zajmuję się migracją $\mathrm{w}$ wymiarze mikrostruktur społecznych, poddając analizie formy życia partnerskiego, małżeńskiego i rodzinnego polskich emigrantów.

\section{Metoda badawcza}

W coraz szerszym zakresie mamy dziś do czynienia z masowym, szybkim i właściwie niekontrolowanym przepływem ludności i informacji, co powoduje, że demografowie są bezsilni wobec zagadnienia oszacowania rozmiarów i liczebności migrantów. Z socjologicznego punktu widzenia kohorta imigrantów w kraju, w którym nie ma ścisłej kontroli granic, obowiązku rejestracji czy meldunku, przybiera postać populacji półukrytej. Legalnie przebywających w Irlandii imigrantów można spotkać niemal na każdym kroku. Nie sposób jednak odnotować, zarejestrować i ująć w miarodajne statystyki ich liczebności oraz miejsca pobytu. Dodatkowo sprawę utrudnia mobilność: zmiana zamieszkania, poszukiwanie pracy, zmiany na rynku pracy. Wobec półukrytego charakteru rozproszonej społeczności polskiej na terenie Irlandii zasadne wydaje się zastosowanie techniki badawczej, pozwalającej przeprowadzić reprezentatywne badania kohorty polskich imigrantów. Chodzi o znaną w literaturze przedmiotu technikę respondent driven sampling ${ }^{9}$. W celu przygotowania gruntu dla tego rodzaju badania należy jednak wpierw dokonać badań próbnych o charakterze pilotażowym. Za takie należy uznać niereprezentatywne badanie ilościowe przeprowadzone przez autora niniejszego artykułu na grupie fokusowej: kohorcie uczestników niedzielnych nabożeństw w języku polskim w kościele St. Saviour's przy Dominick Street w Dublinie.

W ramach dwóch etapów projektu przeprowadziłem dwa badanie ankietowe. Pod koniec maja 2008 r. (4 lata po akcesji Polski do Unii Europejskiej) uczestnikom niedzielnych mszy odprawianych w języku polskim rozdano ankiety. W celu zachowania losowego doboru uczestników badania wręczono ją co trzeciemu dorosłemu (nie wliczano dzieci pod opieką dorosłych) uczestnikowi nabożeństwa. Założone zadanie zostało wykonane w dużym stopniu, choć wystąpiły trudności z równomierną dystrybucją ankiet. Ogółem rozdano 310 kwestionariuszy. Respondenci mieli w kolejną (bądź kolejne) niedzielę zwrócić wypełnione ankiety. Poziom zwrotów, po założonych trzech tygodniach oczekiwania, osiagnął 44,2\% (137 ankiet). $\mathrm{Z}$ uwagi na formę selekcji ankietowanych metoda badawcza preferowała zwroty wypełnionych ankiet przez osoby regularnie uczestniczące $\mathrm{w}$ niedzielnych nabożeństwach. Tym samym w założeniu badana

\footnotetext{
${ }^{9}$ M. S a $\mathrm{lg}$ a n i k, D. H e c k a t h o rn: Sampling and estimation in hidden populations using respondent-driven sampling. ,Sociological Methodology”. R. 2004 nr 34 s. 193-239.
} 
próba charakteryzuje się wysokim poziomem częstotliwości praktyk religijnych. Dobór grupy fokusowej niesie jednak także korzyści badawcze. Przede wszystkim można zebrać cenny materiał dla badań religijności. Mamy bowiem do czynienia z respondentami, którzy nie tylko deklarują udział w praktykach religijnych, ale w nich dość regularnie, rzeczywiście uczestniczą. Poza tym, wobec braku innych silniej rozwiniętych instytucji integrujących polską diasporę, asocjacje religijne są rzadkimi przypadkami luźno powiązanych subpopulacji o pewnym wewnętrznym spoiwie. Społeczność polskich imigrantów gromadzi się w kilkudziesięciu miejscach na terenie Irlandii podczas wspólnych, publicznych nabożeństw w języku polskim. Uczestnicy nabożeństw prowadzonych w języku polskim pozostają w dość regularnym choć powierzchownym kontakcie. Ośrodek duszpasterski i kościół parafialny posiadają potencjał gromadzenia stosunkowo licznej społeczności w obrębie słabo zintegrowanej etnicznej kohorty polskich imigrantów. Wybór tego rodzaju grupy fokusowej jest uzasadniony w rozproszonej i półukrytej populacji polskiej imigracji w Irlandii.

W kolejnym etapie badań w lipcu 2009 jako uczestników badania przyjęto próbę całkowita. Uczestnikom nabożeństw w tym samym kościele, których było w tym czasie 822 , rozdano ankiety. Do badania wybierano osoby dorosłe, z których 605 przyjęło ankiety. Część respondentów w kolejne niedziele bądź drogą pocztową zwróciła je wypełnione. Poziom zwrotów, po założonych trzech tygodniach oczekiwania, osiaggną $37 \%$ (222 ankiet) ${ }^{10}$. Przyjęte problemy i hipotezy badawcze dotyczyły węższej tematyki niż zakres badań z poprzedniego roku. W niniejszym opracowaniu prezentuję i analizuję wyniki badań z zakresu określenia stanu cywilnego, formy życia małżeńsko-rodzinnego, problemu rozbicia rodzin oraz sieci powiązań migracyjnych w obszarze najbliższej rodziny. Mimo, iż efekty realizacji pierwotnej próby w obu badaniach nie były zbyt wysokie, za zadowalającą należy uznać liczbę respondentów, którzy wzięli udział w badaniu. W świetle dotychczasowych prac badawczych w kwestii polskich imigrantów w Irlandii są to próby bardzo liczne ${ }^{11}$. Szczególnie cennym aspektem badawczym

${ }^{10}$ Więcej na temat założeń, celów badawczych oraz metody w: M. L i s a k: Religiousness of Polish Immigrants: Limits of the Secularization Thesis. University of Dublin Trinity College, Irish School of Ecumenics, maszynopis. Dublin 2009 s. 54-59.

${ }^{11}$ Por. E. D e b a e n e: Dialog międzykulturowy. Polska diaspora a spoteczeństwo irlandzkie po roku 2004. Analiza psychologiczno-socjologiczna. W: H. G r z y m a ł a - M o s z c z y ń s k a, A. $\mathrm{K}$ w i a t k o w s ka, J. R o s z a k (red.): Drogi i rozdroża. Migracje Polaków w Unii Europejskiej po 1 maja 2004 roku. Kraków 2010 s. 94; K. K r o p i w i e c, R. K i n g - O ’ R i a i n: Polish Migrant Workers In Ireland. National Consultive Commitee on Racism and Interculturalism Ireland. Dublin 2006; A. R a d i u k i e w i c z: Emigracja zarobkowa Polaków do Irlandii. Raport z badań. Związek Biur Porad Obywatelskich. Warszawa 2006 s. 6. W przypadku niektórych innych badań brak precyzyjnych danych dotyczących zastosowanej metody, w tym także wielkości próby badawczej - por. N. Galica-Orzechowska, P. Gibbons: Proces integracji polskich migrantów na obszarach wiejskich Republiki Irlandii. W: H. Gr z y m a ł a - M o s z c z y ń s k a, A. 
jest natomiast realizacja badań w środowisku osób nie tylko deklarujących, ale rzeczywiście regularnie i często biorących udział w kościelnych praktykach religijnych.

\section{Profil socjodemograficzny badanych}

Na początek zwięzła charakterystyka próby. Badanie ankietowe z $2008 \mathrm{r}$. wskazało na wyraźną dominację osób młodych. W badaniu wzięły udział osoby w przedziale wiekowym 21-57 lat. Dominowały osoby liczące 26-30 lat, które stanowiły aż 51,2\% ogółu. Dwie kolejne co do liczebności kategorie wiekowe to: 31-35 lat $(15,8 \%)$ i $46-50$ lat $(9,8 \%)$. Ponad $2 / 3$ badanych mieści się w przedziale wiekowym 26-35 lat. Średnia wieku ankietowanych to 33 lata $(M=33)$. Młody wiek uczestników nabożeństw u polskich dominikanów w Dublinie jeszcze precyzyjniej oddaje mediana, która wynosi 29 lat $(\mathrm{Me}=29)$. Zdecydowanie dominowali imigranci poakcesyjni (96\%), a średnia długość pobytu respondentów w Irlandii wynosiła 26 miesięcy. Także w 2009 roku dominowały osoby młode o średniej wieku 31,1 lat i medianie 29 lat. Są to także imigranci poakcesyjni (95\%), którzy zamieszkują na Zielonej Wyspie (w lipcu 2009) średnio 35,6 miesięcy (tabela1).

Tabela 1. Ogólna charakterystyka badań i respondentów

\begin{tabular}{|l|c|c|}
\hline Czas badania & maj 2008 & lipiec 2009 \\
\hline Liczba respondentów & $\mathrm{N}=137$ & $\mathrm{~N}=222$ \\
\hline Poziom zwrotu (uczestnictwa) & $44 \%$ & $37 \%$ \\
\hline Przedział wiekowy & $21-57$ lat & $16-62$ lata \\
\hline Średnia wieku & 33 lata & 31,1 lat \\
\hline Średnia wieku (mediana) & 29 lat & 29 lat \\
\hline $\begin{array}{l}\text { Proporcja } \\
\text { mężczyźni - kobiety }\end{array}$ & $\begin{array}{c}62 \% \text { mężczyźni } \\
38 \% \text { kobiety }\end{array}$ & $\begin{array}{c}42 \% \text { mężczyźni } \\
58 \% \text { kobiety }\end{array}$ \\
\hline
\end{tabular}

Źródło: badanie własne ( maj 2008 i lipiec 2009, Dublin)

W grupie badanych z 2008 r. zwraca także uwagę znaczna przewaga mężczyzn. Blisko 2/3 uczestników ankiety to mężczyźni $(62,4 \%)$. Kobiety stanowiły $37,6 \%$. Musimy przy tym pamiętać, że mamy do czynienia z grupą o wysokim

K w i a t k ow s k a, J. R o s z a k (red.): Drogi i rozdroża. Migracje Polaków w Unii Europejskiej po 1 maja 2004 roku. Kraków 2010 s. 300-316. 
profilu uczestnictwa w praktykach religijnych. Z badań socjologicznych w Polsce wynika, że kobiety częściej uczestniczą w praktykach religijnych. Możemy się spodziewać nadreprezentacji kobiet w grupie fokusowej. A zatem, prawdopodobnie w całości populacji polskich imigrantów w Irlandii mężczyźni przeważali w proporcji do kobiet w jeszcze większym stopniu. Podobna dysproporcja może dotyczyć wieku polskiej kohorty etnicznej w Irlandii. Z badań socjologicznych w Polsce wynika, że w praktykach religijnych częściej uczestniczą osoby starsze. Liczba młodych uczestników polskich nabożeństw powinna być mniejsza niż w całości populacji. Dlatego dominująca pozycja ludzi młodych w grupie badanych może wskazywać, że w całej populacji polskich imigrantów proporcje wiekowe na korzyść osób młodych są jeszcze silniejsze.

Odmienne wyniki przynosi badanie z 2009 r., które wykazało przewagę kobiet $-58 \%$. Nie możemy oczywiście dokonywać ekstrapolacji uzyskanych wyników na całą kohortę polskich imigrantów. Jednak znaczne przesunięcie w stronę feminizacji badanej grupy może potwierdzać zmiany w uwarunkowaniach migracyjnych. W 2008 r. do Irlandii dotarł kryzys ekonomiczny. Oprócz kluczowego wstrzasu w sektorze bankowym kryzys spowodował gwałtowny spadek zatrudnienia w sektorze budowlanym. Spadek zapotrzebowania na wysoko i niżej wykwalifikowaną siłę roboczą mógł spowodować odpływ imigrantów zatrudnionych w typowo zmaskulinizowanej branży gospodarki. Odpływ mężczyzn wykonujących prace fizyczne i rzemieślników w nieco starszym wieku może potwierdzać także odmłodzenie w badanej grupie respondentów. Średnia wieku zmniejszyła się o 2 lata.

Dane dotyczące wieku i proporcji płci respondentów wynikające z tego badania na niereprezentatywnej próbie polskich imigrantów są zbieżne z wynikami spisu ludności z kwietnia 2006 r. Wedle opracowania irlandzkiego urzędu statystycznego średnia wieku w kohorcie 63276 polskich imigrantów wynosiła 27,5 lat, a 70\% mieściło się grupie wiekowej 20-34 lata. Zdecydowaną większość stanowili mężczyźni - 64\% (kobiety - 36\%). Blisko 90\% polskich imigrantów przybyło do Irlandii w roku 2004 i później ${ }^{12}$.

\section{IV. Życie osobiste: związki nieformalne, małżeństwo, single}

Znaczące różnice pomiędzy badaną próbą a spisem ludności z 2006 r. wystąpiły natomiast przy określeniu stanu cywilnego, czy też raczej form życia w

${ }^{12}$ Central Statistics Office Ireland: Census 2006. Non-Irish Nationals Living in Ireland. Dublin 2008 s. 28-30. 
związkach interpersonalnych ${ }^{13}$. W celu adekwatnego określenia formy życia samotnego bądź w związku badacz posłużył się bardziej precyzyjnymi kategoriami. Popularnie stosowane kategorie stanu cywilnego, takie jak: kawaler/panna, małżeństwo, rozwiedziony/w separacji, wdowieństwo zostały poszerzone i doprecyzowane. Wiąże się to z przemianami w zakresie form życia partnerskiego, małżeńskiego i rodzinnego, które obserwowane są we współczesnej ponowoczesnej kulturze ${ }^{14}$. Respondenci mieli za zadanie określić swą przynależność do jednej z 8 kategorii. Kategoryzacja została dokonana z uwzględnieniem specyfiki religijno-małżeńskiej katolicyzmu oraz stanu życia w związku (m.in. małżeństwie) bądź bez trwałego związku z druga osobą. Kategorie: „małżonek (pierwsze małżeństwo)”, „małżonek (po raz kolejny)”, „w związku niemałżeńskim (mieszkanie razem)", „w związku niemałżeńskim (nie mieszkający razem)" określają różnorodne formy życia w aktualnym związku z drugą osobą. Pozostałe kategorie określają formę życia bez partnera czy małżonka, czyli oddają (w pewnym przybliżeniu) zakres znaczeniowy pojęcia ,singiel”. Sa to: ,singiel (bez stałego związku)”, „,singiel (wdowieństwo)”, ,singiel (po rozwodzie albo po uznaniu nieważności małżeństwa kościelnego)”, „małżonek (w separacji)"15. Odpowiedzi respondentów są przedstawione w tabeli 2, która zestawia wyniki badania z 2008 i 2009 r.

W obu badaniach uzyskano podobne profile form życia osobistego. Około połowa respondentów (w 2009 r. jednak o blisko 5 pkt. procentowych więcej niż w 2008) wskazała, że jest mężem bądź żoną w swoim pierwszym małżeństwie. Co najbardziej zastanawiające, w kohorcie katolików regularnie uczestniczących w kościelnych nabożeństwach aż $28 \%$ badanych w 2008 r. potwierdziło, że żyje w kohabitacji - w związku niemałżeńskim, mieszkając razem. Odsetek ten okazał się niższy w 2009 r., ale dalej co piąta osoba badana (19,8\%) określiła swoją formę życia jako kohabitację. W obu latach co piąty badany wskazał, że jest singlem, pozostającym bez stałego związku życiowego. Gdy do tej subpopulacji dodamy singli-wdowców (4,1\% w 2009), singli-rozwodników $(1,8 \%)$ i małżonków w separacji $(1,4 \%)$, otrzymujemy skumulowany odsetek $27,1 \%$ osób żyjących w 2009 r. poza aktualnym związkiem życiowym (samotnych, singli). Ta sama zbiorcza kategoria obejmowała w 2008 roku 19,7\% respondentów. Pozo-

${ }^{13}$ Wedle spisu ludności z 2006 r. pośród polskich imigrantów 62\% stanowili kawalerowie i panny, 34\% osoby żyjące w małżeństwie, a $4 \%$ rozwiedzeni oraz żyjący w separacji. Central Statistics Office Ireland: Census 2006. Non-Irish Nationals Living in Ireland. Dublin 2008 s. 30.

${ }^{14}$ Por. K. S 1 a n y: Alternatywne formy życia matżeńsko-rodzinnego $w$ ponowoczesnym świecie. Kraków 2002.

${ }^{15}$ Umieszczenie tej kategorii w grupie singli jest dyskusyjne, ale na potrzeby niniejszej pracy dokonujemy takiego uproszczenia. 
stała część badanej próby żyje w małżeństwie (pierwszym i ponownym) bądź w związku z partnerem (kohabitacja albo stały związek bez wspólnego zamieszkiwania). W 2008 r. było to $77,3 \%$, a w 2009 r. - 72,1\%: przy czym spadł odsetek kohabitacji a wzrósł odsetek żyjących w pierwszym małżeństwie.

Tabela 2. Społeczne formy życia (w procentach)

\begin{tabular}{|l|c|c|}
\hline \multirow{2}{*}{ Forma życia osobistego } & \multicolumn{2}{c|}{ Rok badania } \\
\cline { 2 - 3 } & 2008 & 2009 \\
\cline { 2 - 3 } & $\mathrm{N}=137$ & $\mathrm{~N}=222$ \\
\hline małżonek (pierwsze małżeństwo) & 46,0 & 50,9 \\
\hline małżonek (w separacji) & - & 1,4 \\
\hline małżonek (po raz kolejny) & - & 1,4 \\
\hline singiel (wdowieństwo) & - & 4,0 \\
\hline singiel (po rozwodzie albo po uznaniu nieważności mał- & - & 1,8 \\
\hline żeństwa kościelnego) & & 19,8 \\
\hline singiel (bez stałego związku) & 19,7 & 19,8 \\
\hline w związku niemałżeńskim (mieszkanie razem) & 27,7 & - \\
\hline w związku niemałżeńskim (nie mieszkający razem) & 3,7 & 0,9 \\
\hline brak odpowiedzi & 2,9 & 100,0 \\
\hline Ogółem & 100,0 & \\
\hline
\end{tabular}

Źródło: badanie własne ( maj 2008 i lipiec 2009, Dublin)

\section{Emigracyjna rozłąka}

Opierając się na danych wynikających z irlandzkiego spisu ludności, jako problem badawczy postawiono pytanie o zakres rozłąki. Dane demograficzne z 2006 r. wskazywały, że w kohorcie polskich imigrantów 59\% żonatych mężczyzn w dniu przeprowadzenia spisu nie mieszkało razem ze swoimi małżonkami. W przypadku zamężnych kobiet blisko co piąta (19\%) nie mieszkała ze swoim mężem. Trzeba jednak pamiętać, że odsetek małżonków w całej badanej ko- 
horcie etnicznej wynosił $34 \%{ }^{16}$. Dane te mogą wskazywać na niemały problem rozbicia emigracyjnych małżeństw i rodzin. Dodatkowo, niektóre z badań dotyczących polskiej emigracji zarobkowej w XXI wieku wskazuja, że rzadko mamy do czynienia $\mathrm{z}$ emigracją pełnych rodzin wraz z dziećmi. Wśród rodzin z dziećmi uczestniczqcych $w$ migracji, tylko co piqte matżeństwo i co dziesiqta para decyduje się na wyjazd $w$ całości. Zdecydowana większość rodzin uczestniczqcych $w$ migracji deleguje do pracy za granica jednego lub dwoje członków a inni pozostaja $w$ kraju ${ }^{17}$. Wskaźniki te posłużyły do przyjęcia w badaniach z $2008 \mathrm{r}$. założenia, że rozłączenie małżeństw i rodzin jest poważnym problem dla polskich imigrantów w Irlandii.

Dwie główne zbiorcze kategorie, oszacowane w poprzednim rozdziale na podstawie przyjętych zmiennych, pozwalają określić o wiele dokładniej potencjalny problem samotności, rozłąki bądź rozbicia związku (np. separacja). Wśród badanych w 2008 r. co piąta osoba żyła bez stałego partnera życiowego, a w 2009 r. sytuacja taka dotyczyła co czwartego respondenta. Rozłąka może jednak dotyczyć także małżonków czy partnerów, którzy w wyniku migracji zostali czasowo rozdzieleni. Dlatego też w badaniu z 2008 r. respondentów zapytano: czy mieszkasz w Irlandii razem ze swoim współmałżonkiem bądź stałym partnerem (partnerka)? Zdecydowanie ponad połowa respondentów $(57,7 \%)$ potwierdziła, że mieszka razem $^{18}$. Z kolei co piąty ankietowany (19\%) stwierdził, że nie mieszka ani $\mathrm{z}$ małżonkiem, ani z nieformalnym partnerem, ponieważ jest singlem. Wedle pozostałych odpowiedzi, w 22,6\% przypadków mamy jednak do czynienia z małżonkami mieszkającymi w Irlandii bez swoich współmałżonków czy żyjącymi w stałych pozamałżeńskich związkach a mieszkającymi na co dzień bez partnerów.

$\mathrm{W}$ podsumowaniu należy podkreślić, że $\mathrm{w}$ irlandzkim środowisku emigracyjnym (w 2008 r.), które może często przysparzać doświadczenia wykorzenienia, zgubienia, osamotnienia, co piąty $(19,7 \%)$ spośród badanych żyje jako singiel bez stałego związku; a także co piąty $(22,6 \%)$ spośród badanych jest małżonkiem bądź partnerem nieformalnym, żyjącym w rozłące.

W dobie dobrowolnych i wymuszonych migracji bardzo istotnym problem społecznym stała się nie tylko rozłąka czy rozpad związków i małżeństw, ale

\footnotetext{
${ }^{16}$ Por. Central Statistics Office Ireland: Census 2006. Non-Irish Nationals Living in Ireland. Dublin 2008 s. 30.

${ }^{17}$ Z. K a w c z y ń s k a - B u t r y m: Migracja: Perspektywa mikrospoteczna - indywidualne $i$ rodzinne zyski, koszty i straty. W: M. Z i ę b a (red.): Migracja-wyzwanie XXI wieku. Lublin 2008 s. 117.

${ }^{18}$ Przy czym w tej subpopulacji aż 48\% określiło swoją formę związku nie jako małżeństwo, ale jako związek nieformalny - kohabitację.
} 
także szerzej rozumiane rozbicie rodzin ${ }^{19}$. W świetle polityki społecznej, w zakresie działań i badań prawnych oraz wielu dociekań socjologicznych i psychologicznych popularnym i palącym zagadnieniem migracyjnym stało się łączenie rodzin (family reunification) rozbitych migracjami ${ }^{20}$. Zagadnienie to znalazło się częściowo w zakresie przeprowadzonych badań. W tym obszarze tematycznym ankietowani wpierw odpowiedzieli na pytanie o posiadanie dzieci i miejsce ich zamieszkania (tabela 3).

Tabela 3. Miejsce zamieszkania dzieci (w procentach)

\begin{tabular}{|l|c|}
\hline \multirow{2}{*}{ Moje dziecko/dzieci mieszka/-ją } & Rok badania 2008 \\
\cline { 2 - 3 } & $\mathrm{N}=137$ \\
\hline w Polsce & 20,4 \\
\hline w Irlandii & 8,8 \\
\hline w Polsce i Irlandii & 2,9 \\
\hline w innym kraju (krajach) & - \\
\hline nie mam dzieci & 67,9 \\
\hline brak odpowiedzi & - \\
\hline Ogółem & 100,0 \\
\hline
\end{tabular}

Źródło: badanie własne ( maj 2008, Dublin)

Zdecydowana większość respondentów, ponad 2/3 nie posiada w ogóle dzieci. Należy pamiętać, że są to ludzie młodzi, spośród których tylko połowa żyje w małżeństwie. $\mathrm{W}$ ich przypadku nie ma mowy o rozbiciu przez migrację własnej najbliższej rodziny i ,migracyjnym osieroceniu” dzieci (tzw. eurosierot). Ci młodzi ludzie, nawet jeżeli są małżeństwem, to jeszcze nie weszli w fazę tworzenia rodziny prokreacyjnej. Jednak w przypadku co czwartego respondenta $(23,3 \%)$ mamy do czynienia z rozłąką z dziećmi, bądź jednym z dzieci

${ }^{19}$ Z. K a w c z y ń s k a - B u t r y m, dz. cyt., s. 109-111.

${ }^{20}$ Por. R. Ch o l e w i n s k i: Family Reunification and Conditions Placed on Family Members: Dismantling a Fundamental Human Right. „European Journal of Migration and Law”. R. $2002 \mathrm{nr} 4$ s.271-290; A. G e d d e s: The Politics of Migration and Immigration in Europe. London 2003; E. K o f m a n: Family Related Migration: a Critical Review of European Studies. „Journal of Ethnic and Migration Studies". R. 2004 nr 30(2) s. 243-262; J. L i t t e 11, J. S c h u e r m a n: A synthesis of research on family preservation and family reunification programs. Chicago 1995; S. Mullally: Children, citizenship and constitutional change. W: B. F a n n i n g (red.): Immigration and social change in the Republic of Ireland, Manchester 2007 s. 27-46. 
(odpowiedzi: „w Polsce” i „w Polsce i Irlandii”). Z punktu widzenia obiektywnych warunków życiowych - mieszkania w oddzielnych państwach - oraz z punktu widzenia rozłąki z partnerami życiowymi, problem rozłąki i rozbicia rodzin i związków, a zarazem potrzeba łączenia rodzin wydają się istotne ${ }^{21}$.

W kolejnym pytaniu badawczym respondenci mieli wskazać zakres spotkań z członkami najbliższej rodziny. Ankietowanych zapytano o fakt i formę zaproszenia bądź sprowadzenia do Irlandii kogoś z najbliższej rodziny (tabela 4).

Tabela 4. Zakres sprowadzenia członków rodziny do Irlandii (w procentach)

\begin{tabular}{|c|c|}
\hline \multirow{2}{*}{$\begin{array}{l}\text { W trakcie pobytu w Irlandii sprowadziłam/-em } \\
\text { kogoś z najbliższej rodziny }\end{array}$} & Rok badania 2008 \\
\hline & $\mathrm{N}=137$ \\
\hline na stałe & 4,4 \\
\hline na dłużej do opieki nad dzieckiem & - \\
\hline na dłużej do pracy zarobkowej & 19,7 \\
\hline na dłużej na wypoczynek & 4,4 \\
\hline na krótko w odwiedziny & 40,9 \\
\hline w innym celu & 2,9 \\
\hline nie sprowadziłam/-em & 38 \\
\hline \multirow[t]{2}{*}{ brak odpowiedzi } & - \\
\hline & $\begin{array}{l}\text { Procenty nie sumują się do } 100 \text {, ponieważ } \\
\text { respondenci mogli udzielić więcej niż jednej } \\
\text { odpowiedzi. }\end{array}$ \\
\hline
\end{tabular}

Źródło: badanie własne ( maj 2008, Dublin)

Bardzo mało osób sprowadziło członka swej najbliższej rodziny na stałe (4\%). Podobnie niewielki odsetek sprowadził kogoś z rodziny do pracy zarobkowej w Irlandii (co piąta osoba). Wskazuje to na dość mały zakres rodzinnych sieci migracyjnych wśród badanych. Najczęściej członkowie najbliższej rodziny przyjechali do polskich imigrantów w odwiedziny bądź na wypoczynek (razem 45\%). Taka forma kontaktów jest ułatwiona dobrymi warunkami komunikacyjnymi. Silnie rozwinięta jest sieć połączeń lotniczych między trzema lotniskami w

${ }^{21}$ Por. J. P l e w k o: Instytucjonalne formy opieki nad emigracja z ziem polskich. Zarys problematyki. „Roczniki Nauk Społecznych KUL”. R. 2009 nr 1(37) s. 134. 
Irlandii i większością polskich portów lotniczych. Ceny biletów nie są wygórowane, a czas samego przelotu mieści się w 2-3 godzinach.

Zastanawiająca jest podgrupa 38\% badanych, którzy nie sprowadzili nikogo ze swojej najbliższej rodzin, nawet w odwiedziny. W tym miejscu trzeba przypomnieć, że średnio badani przebywają w Irlandii już od 26 miesięcy. Brak spotkania z kimś z rodziny w Irlandii można tłumaczyć tym, że respondenci sami często podróżują w odwiedziny. Zdecydowana większość ankietowanych $(89,8 \%)$ wskazała, że odwiedza Polskę co najmniej 2 razy w roku. Przy czym jedna trzecia $(32,9 \%)$ czyni tak 3 razy w roku, jeden na pięciu respondentów $(20,4 \%)$ podróżuje 4 razy w roku, a $17,5 \%$ badanych wyjeżdża 5 razy w roku i częściej. Znikomy odsetek respondentów, tylko 2,2\%, wskazał, że nie podróżuje do Polski każdego roku.

Dane te, wraz z niewielkim odsetkiem sprowadzenia na stałe, moga potwierdzać hipotezę o przejściowym i niepełnym charakterze polskiej emigracji do Irlandii ${ }^{22}$. Zmienne takie jak posiadanie dzieci, rozłąka $\mathrm{z}$ małżonkiem lub partnerem, rozłąka z dzieckiem, nie różnicują odpowiedzi na pytanie o sprowadzenie do Irlandii kogoś z najbliższej rodziny.

Tabela 5. Samoocena relacji rodzinnych w warunkach emigracyjnych (w procentach)

\begin{tabular}{|l|c|c|}
\hline $\begin{array}{l}\text { Z powodu pobytu w } \\
\text { Irlandii twoje relacje } \\
\text { z najbliższą rodziną }\end{array}$ & pogorszyły się & poprawiły się \\
\hline zdecydowanie nie & 51,1 & 7,3 \\
\hline raczej nie & 34,3 & 30,7 \\
\hline raczej tak & 4,4 & 28,5 \\
\hline zdecydowanie tak & 1,4 & 8,0 \\
\hline trudno powiedzieć & 8,8 & 25,5 \\
\hline Ogółem & 100,0 & 100,0 \\
\hline
\end{tabular}

Źródło: badanie własne ( maj 2008, Dublin)

${ }^{22}$ Taki przejściowy charakter wyjazdów - formę migracji niepełnej wskazują w swoich badaniach I. G r a b o w s k a - L u s i ń s k a i M. O k óls ki: Emigracja ostatnia?. Warszawa 2009 s. $37-61$. 
Ostatnią fazą badania dotyczącego problemu rozłąki migracyjnej i rozbicia rodzin była samoocena natury psychologicznej. Respondenci mieli za zadanie dokonać samooceny stanu swoich relacji rodzinnych w warunkach migracji. Badanych zapytano o poprawę i o pogorszenie relacji rodzinnych, konstruując pytania na zasadzie awersu i rewersu (tabela 5).

W zdecydowanej większości respondenci zaprzeczyli pogorszeniu relacji z najbliższą rodziną. Procent skumulowany dla odpowiedzi „zdecydowanie nie” i „raczej nie” wynosi aż 85,4\%. Tak zdecydowana odpowiedź wydaje się mieć znacznie pozytywne: w samoocenie większości respondentów ich relacje rodzinne nie ulegają pogorszeniu. Jednakże musimy pamiętać o skłonności do lepszej samooceny i niechęci do przyznawania się do porażek. Być może respondenci nie zauważają też problemów związanych z migracją, rozłąką i osłabieniem kontaktów. W pytaniu o odwróconym zakresie już tylko co trzeci badany (procent skumulowany 36,5\%) ocenił, że relacje rodzinne poprawiły się. Znaczna część respondentów nie była $\mathrm{w}$ stanie odpowiedzieć na pytanie o poprawę relacji $(25,5 \%)$. Wobec tego, że w ocenie pozostałych $38 \%$ relacje nie poprawiły się, można stwierdzić, że migracja do Irlandii (która geograficznie i komunikacyjnie jest bliska Polsce) nie wpłynęła ani negatywnie, ani pozytywnie na rodzinne relacje respondentów. Nawet jeśli poszczególni imigranci żyją w stanie rozłąki, nie wpływa to, w ich subiektywnej ocenie, negatywnie na stan relacji rodzinnych, małżeńskich czy partnerskich. Na podstawie takiej samooceny trudno wyciągnąć jednak silnie uzasadnione wnioski. Migranci mogą nie zdawać sobie sprawy z przemian sytuacji rodzinnej i przemian związku z partnerem życiowym. W każdym razie wysoki poziom zaprzeczenia pogorszeniu relacji (deklarowany zdecydowanie aż przez $51 \%$ badanych) potwierdzać może, że w życiu większości respondentów nie nawarstwiają się problemy rozłąki i rozbicia życia rodzinnego. Zmienne takie, jak posiadanie dzieci, rozłąka z małżonkiem lub partnerem, rozłąka z dzieckiem nie różnicują odpowiedzi na pytanie o stan relacji w rodzinie.

Z uwagi na brak przeszkód prawnych polscy imigranci w Irlandii mogą sprowadzić swoich najbliższych. O takim wyborze decydują więc, obok sfery psychologicznej i wewnętrznej osobistej, głównie względy ekonomiczne oraz całościowa strategia migracyjna. Jeśli emigrant nie jest przekonany do dalszego pozostawania za granica, albo jest to tylko czasowy wyjazd zarobkowy, trudno spodziewać się podjęcia decyzji o sprowadzeniu pozostałej części rodzin. Poczucie przejściowego stanu migracji może powodować, że sprawy rodzinne, w tym także trudności rozłąki czy rozbicia związków i rodzin, wydają się dla wielu również tylko przejściowe. Niepełność i niepewność migracyjna niosą jednak za sobą wiele negatywnych skutków. Jeszcze w dobie emigracji przedakcesyjnej o tymczasowości migracji zarobkowej pisał M. Okólski: Migracja niepetna obej- 
muje ludzi z reguty niezdolnych do [...] uzyskania $w$ kraju stabilnej pozycji zawodowej $w$ głównym nurcie jego gospodarki, a jednocześnie osoby potrafiace wykorzystać okazje do zdobycia dochodu w krajach docelowych, choć za cene pozostawania $w$ nich $w$ sytuacji tymczasowości, nielegalności $i$ podwyższonego ryzyka ${ }^{23}$. Po polskiej akcesji do Unii Europejskiej sytuacja pod względem prawnym i ekonomicznym uległa poprawie. Nie mamy do czynienia, zwłaszcza w przypadku Irlandii, z nielegalnością pracy bądź z podwyższonym ryzykiem społecznym migracji. Niebezpieczeństwem trwania w „stanie zawieszenia” jest jednak marginalizacja społeczna i wyobcowanie, zarówno w Polsce jak i w krajach docelowych. Marginalizacji łatwiej podlega osamotniona jednostka czy czasowo osierocona mikrostruktura, jaką jest dotknięta rozłąką rodzina (pozostająca w kraju pierwotnym).

\section{Popularność kohabitacji wśród polskich katolików}

Jak zostało zaprezentowane wcześniej (w tabeli 2), obok problemu rozbicia mikrostruktur społecznych, zastanawiający jest fakt bardzo częstych przypadków kohabitacji. Wedle badania z 2008 r. aż 27,7\% respondentów przyznało się do nieformalnego (niemałżeńskiego) stałego związku i zamieszkiwania z partnerem. Ten odsetek należy uznać za bardzo wysoki szczególnie dlatego, że badane osoby to katolicy regularnie uczestniczący w mszy w ośrodku duszpasterstwa emigrantów. Wyniki badań z 2008 r. spowodowały, że w zakresie form życia małżeńsko-rodzinnego punktem zainteresowania w kolejnym etapie badań stały się częste przypadki kohabitacji wśród uczestników nabożeństw kościelnych. Także w badaniu z lipca 2009 r. uwidocznił się wysoki (jak na praktykujących katolików) odsetek osób żyjących w kohabitacji - 19,8 \%.

Ujawnione w badaniach zjawisko popularności kohabitacji jest przedmiotem dalszych analiz. Trzeba jednak w tym miejscu poczynić ważną uwagę metodologiczną. Badania socjologiczne nie rozstrzygają o naturze religii, ani o wewnętrznych przekonaniach i przeświadczeniach, którymi kierują się poszczególne jednostki. Istota religii oraz sens i treść osobistej religijności pozostają poza zasięgiem metody i poza aspiracjami badawczymi socjologii. Niemniej jednak socjologiczne ujęcie badawcze prowadzi do lepszego poznania społecznego wymiaru zjawiska religijności. Opis społecznych uwarunkowań oraz wypracowane teorie socjologiczne mogą być cennym materiałem dla nauk podejmujących temat reli-

${ }^{23}$ M. O k ó $1 \mathrm{~s}$ k i: Mobilność przestrzenna z perspektywy koncepcji migracji niepetnej. W: E. J a d ź w iń s k a, M. O k óls ki (red.): Ludzie na huśtawce. Migracje między peryferiami Polski $i$ Zachodu. Warszawa 2001 s. 60. 
gii: filozofii czy teologii ${ }^{24}$. Zadaniem socjologii religii i socjologii moralności nie jest $\mathrm{w}$ tym miejscu dokonywanie oceny czy przemiany nauczania religijnomoralnego. Dzięki badaniom i analizie socjologicznej zyskujemy jednak mocno osadzony w empirii punkt odniesienia dla rozumienia społecznych postaw i interakcji.

W zakresie sposobu życia, a w szczególności form życia małżeńskorodzinnego, katolickie instytucje posługują się przede wszystkim oficjalnym nauczaniem Kościoła w zakresie moralności, sakramentów, zadań pastoralnych (duszpasterskich). Kościół katolicki w swym nauczaniu formułuje wytyczne moralne i określa pewien model (modele) dobrego, prawego życia. Odnośnie do życia rodzinnego fundamentem jest zawarcie sakramentalnego związku małżeńskiego. Kościół prezentuje szereg wymogów i zasad. Jedność i wzajemna odpowiedzialność małżonków za siebie nawzajem ma charakter obligatoryjny. Jedność małżeńska w swej dozgonnej nierozerwalności i wyłączności jest ,uświęcona", ustanowiona i zdefiniowana interwencją Boga. Przygotowanie do małżeństwa powinno przebiegać w sposób stopniowy, jednakże bez tworzenia wspólnoty życia narzeczonych na wzór pożycia małżeńskiego. Dopiero wspólnota małżeńska (mężczyzny i kobiety), zapoczątkowana ślubem, powinna prowadzić wspólne gospodarstwo domowe, zamieszkiwać razem, podejmować współżycie seksualne, które ukierunkowane jest na prokreację i wyraża jednoczącą więź. Tymczasem problem przemiany stylu życia i modeli przygotowania do małżeństwa nie jest bardziej gruntownie podejmowany w nauczaniu i praktyce pastoralnej Kościoła katolickiego. W sprawie konkubinatu czy kohabitacji wydaje się dominować ton parenezy. Popularne stanowisko sprowadza się do konstatacji: Kościót sprzeciwia się modelowi zwiazków nieformalnych jako formie życia rodzinnego, oraz formie przygotowania do matżeństwa ${ }^{25}$.

Ten model, który w świetle badań historyczno-doktrynalnych został wypracowany w ostatnich stuleciach, wydaje się być charakterystyczny i dopasowany do tradycyjnych społeczności. Używając w tym kontekście słowa „tradycyjny”, mam na myśli typ życia społecznego bliższy raczej Gemeinschaft Tönniesa: silnym wpływom środowiskowym, ścisłym więziom w małych społecznościach, jednolitym wzorcom obyczajowo-kulturowym. W wysoce zurbanizowanym i mobilnym społeczeństwie poczucie lokalnej przynależności słabnie, podobnie jak więzi społeczne, intensywne więzi lokalne, szczególnie grup pierwotnych, ulegają rozprężeniu, indywidualizacji, anonimowości. Wzrastająca mobilność

\footnotetext{
${ }^{24}$ Por. J. M a r i a ń s k i: Czy Kościót jest przeciwny badaniom socjologicznym? W: M. R u s e c k i (red.): Problemy wspótczesnego Kościoła. Lublin 1997 s. 246, 256.

25 A. K ołki e wi c z: Zwiazki nieformalne jako wspótczesne wyzwanie dla działalności formacyjnej Kościoła. „Studia Gdańskie”. T. 23: 2008 s. 264.
} 
przestrzenna osłabia społeczną presję płynącą ze strony grup pierwotnych. Zwłaszcza kiedy młodzi ludzie przemieszczają się w środowisko odległe od świata ich wczesnej socjalizacji, „tradycyjna” presja środowiskowa maleje. Wraz z rozwojem sieci komunikacji społecznej do poszczególnych jednostek dociera coraz więcej wzorców i modeli kulturowych, także tych z zakresu sfery życia małżeńsko-rodzinnego ${ }^{26}$. Prowadzi to do detradycjonalizacji, poszerza znajomość różnorodnych i często konkurencyjnych modeli dobrego życia, stanowi o wszechobejmującym pluralizmie form życia społecznego. Detradycjonalizacja i relatywizacja kulturowa sposobów życia jest jednym z aspektów procesów globalizacji ${ }^{27}$, w które przecież w pełni wpisują się migracje zagraniczne.

Zakaz moralny, dotyczący życia w związkach przedmałżeńskich (czy pozamałżeńskich), dotyczy przede wszystkim sfery seksualności. Taki akcent w nauczaniu moralnym nie odnosi się jednak w pełni do wielu innych aspektów budowania relacji interpersonalnych. W obserwowanym przypadku polskich imigrantów-katolików w Dublinie możemy przypuszczać, że współzamieszkiwanie par i narzeczonych nie sprowadza się do kwestii ,próbowania” współżycia seksualnego. Młodzi ludzie, często czujący się obco w warunkach emigracyjnych, wybierają związek, który prowadzi do wspólnoty codziennego życia. Partnerzy dają sobie poczucie wsparcia, bliskości, pomocy - co jest szczególnie cenne w docelowym miejscu migracji. Niebagatelne znaczenie mają także czynniki ekonomiczne. Mieszkanie razem, współwynajmowanie mieszkania jest znacznie tańsze i bardziej praktyczne z uwagi na świadczoną sobie na co dzień pomoc. $\mathrm{Na}$ emigracji, także tej wewnątrzkrajowej, na przykład przy wyjeździe na studia, w dużych społecznościach ludzkich (dużych miastach, gdzie życie jest bardziej anonimowe) nawet osoby, które zostały wychowane wedle innych (bardziej ,tradycyjnych") zasad, przyjmują kohabitację jako nowy model rozwoju swojego związku życiowego ${ }^{28}$.

Szeroka reprezentacja ludzi żyjących w kohabitacji wśród polskich imigrantów w Dublinie jest przykładem poważnych przemian w zakresie moralności i religijności. Zachodzą one nie tylko poza murami kościołów, ale także w środowisku ludzi o wysokim poziomie religijności kościelnej. Analiza formy kohabitacji dokonana na podstawie badań w 2008 i 2009 r. prowadzi do wniosku, że mamy do czynienia głównie z kohabitacją czasową, która najczęściej może zakończyć się wraz z zawarciem małżeństwa ${ }^{29}$. Jak już zaznaczono wcześniej (ta-

${ }^{26}$ K. S 1 a n y, dz. cyt., s. 183.

${ }^{27}$ Por. E. W n u k - Li p i ń s k i: Świat międzyepoki. Kraków 2004 s. 37-40.

${ }^{28}$ K. S 1 a n y, dz. cyt., 183-184.

${ }^{29}$ Zaprezentowane wnioski mają swoją podstawę w badaniach i analizie dokonanej w M. L i s a k: Religijność a poglady moralne katolików żyjacych $w$ kohabitacji: na przykładzie polskich emigrantów w Dublinie. Referat na konferencji naukowej „Między nakazem a wyborem. Moralne 
bela 2), w drugim badaniu (2009) odsetek przyznających się do kohabitacji zmalał o 8 punktów procentowych. Jednocześnie obserwujemy wśród badanych z 2009 r. większy udział małżonków w pierwszym małżeństwie (wzrost o 5 punktów procentowych). Dane te mogą wskazywać, że część osób żyjących jeszcze w 2008 roku w kohabitacji zawarła związek małżeński i dalej uczęszcza do polskiego duszpasterstwa w kościele St. Saviour's. Przy jednoczesnym założeniu, że liczebność polskiej społeczności w Irlandii nie przyrasta lecz raczej stopniowo maleje ${ }^{30}$, potwierdzałoby to czasowy charakter kohabitacji. Dla wielu uczestników kościelnych nabożeństw w języku polskim w Dublinie kohabitacja jest formą rozwoju związku interpersonalnego i fazą przygotowania do małżeństwa. Poza tym aż 98\% spośród respondentów żyjących w kohabitacji z badania w 2008 r. wskazało, że nie posiada dzieci. Są to więc młodzi ludzie, których wzajemne związki nie doprowadziły do utworzenia własnej rodziny prokreacyjnej.

Potwierdzenie dla tych obserwacji i wniosków znajdziemy też w statystykach prowadzonych przez dominikańskie duszpasterstwo dla polskich imigrantów w Dublinie ${ }^{31}$. W tym samym kościele, gdzie przeprowadzono badania ankietowe w 2008 i 2009 r. ma miejsce stosunkowo duża liczba chrztów małych dzieci. Prowadzone są też licznie uczęszczane kursy przedmałżeńskie, które w Irlandii i w Polsce są elementem obowiązkowego przygotowania do zawarcia ślubu kościelnego. W kilkunastu seriach kursów, od maja 2006 do czerwca 2010, wzięło udział w duszpasterstwie przy kościele St. Saviour's aż 1860 osób, w tym 917 par.

W szczegółowych zestawieniach statystycznych obejmujących 8 serii kursów przedmałżeńskich, prowadzonych w latach 2008-2010, odnotowano uczestnictwo 408 par. Aż w 361 przypadkach (88,5 \%) osoby (narzeczeni) zgłaszające się na kurs podawały ten sam adres zamieszkania. Świadczy to, że zdecydowana większość tych par (narzeczonych) katolików w warunkach imigracyjnych w Dublinie przed ślubem pozostawała w związku o charakterze kohabitacji. Wspólne zamieszkiwanie jest dla nich etapem życia przed zawarciem ślubu kościelnego - swoistym przygotowaniem do małżeństwa.

Kohabitacja jest też obserwowana przy okazji chrztów dzieci. Od powstania duszpasterstwa w lutym 2000 aż do końca września 2010 r. udzielono 318

\footnotetext{
dylematy małżeństw i rodzin w Polsce”, Instytut Socjologii, Uniwersytet im. Adama Mickiewicza w Poznaniu, 22 kwietnia 2010 (w przygotowaniu do druku).

30 Takie założenia znajdują potwierdzenie $w$ niepełnych danych statystycznodemograficznych irlandzkich urzędów.

${ }^{31}$ Statystyki dostępne w raporcie - M. Gru b k a: Polish Chaplaincy in Dublin: „Dominicans for Poles". Report 14.02.2006 -29.09.2010. Dublin 2010 [Archiwum Irlandzkiej Prowincji Dominikanów].
} 
chrztów dzieciom polskich rodziców. W 158 przypadkach rodzice chrzczonych dzieci byli małżeństwem sakramentalnym w świetle przepisów Kościoła katolickiego. Jednak w tej subpopulacji nieznaczną większość stanowili rodzice, którzy nie zawarli ze sobą ślubu kościelnego (160 chrztów). W tym przypadku brakuje danych pozwalających na rozróżnienie, kto z tych rodziców żyje w kohabitacji (konkubinacie), a kto w cywilnym związku małżeńskim. Trudno zatem oszacować w tej grupie skalę kohabitacji. Jeśli jednak nawet mniejsza część wskazanych rodziców żyje w bez formalnego związku małżeńskiego, to w takim razie mamy do czynienia z formą bardziej trwałej kohabitacji (kohabitujące pary posiadają wspólne potomstwo). W przypadku chrztów dzieci urodzonych poza sakramentalnym związkiem małżeńskim możemy mieć jednak do czynienia z odrębną subpopulacją polskich imigrantów. Mam na uwadze odrębność wobec regularnych uczestników mszy w języku polskim, którzy byli grupą fokusową naszych badań. Rodzice, którzy sami nie żyją w sakramentalnym związku małżeńskim, mogą pojawiać się w kościele dość rzadko i wyjątkowo, na przykład jedynie z okazji sakramentu chrztu własnych dzieci. Możemy zatem postawić hipotezę o występowaniu dwóch subpopulacji żyjących w kohabitacji. Zmienną różnicującą jest w tym przypadku częstotliwość i regularność uczestniczenia w kościelnych praktykach religijnych.

Z punktu widzenia socjologii religii sam fakt podjęcia kohabitacji, prawdopodobnie jako formy przygotowania do małżeństwa, oraz inne cechy religijnomoralne świadczą, że znaczna cześć respondentów prezentuje religijność zindywidualizowana, wybierając pewne praktyki religijne, a pomijając znaczenie systemu moralnego wypracowanego przez katolicyzm. Na poziomie statystycznie istotnym żyjący w kohabitacji opowiadają się częściej (niż małżonkowie i single) za: dopuszczeniem do Komunii osób żyjących w związkach niesakramentalnych, akceptacją moralną seksu przedmałżeńskiego. $Z$ kolei, na poziomie statystycznie istotnym, żyjący w kohabitacji rzadziej wyrażają aprobatę dla treści i sposobu nauczania Kościoła na temat życia rodzinnego. Rzadziej także modlą się osobiście, rzadziej przystępują do Komunii i spowiedzi, rzadziej uczestniczą w mszy. Co jednak ciekawe i sprzeczne z oficjalnym nauczaniem i praktyką Kościoła katolickiego, blisko połowa $(47,6 \%)$ kohabitujących deklaruje przystępowanie do Komunii kilka razy w roku, co jest najbardziej popularną częstotliwością tej praktyki religijnej w całej badanej grupie ${ }^{32}$.

\footnotetext{
${ }^{32}$ Szczegółowa analiza: M. L i s a k: Religijność a poglady moralne katolików żyjacych $w$ kohabitacji: na przykładzie polskich emigrantów w Dublinie, dz. cyt.
} 
W podsumowaniu musimy podkreślić, że migracja zagraniczna wywiera znaczący wpływ na funkcjonowanie związków partnerów, małżonków oraz rodzin. Wśród części polskich imigrantów w Dublinie obserwujemy doświadczenia rozłąki małżeńsko-rodzinnej. Diagnoza doświadczanej przez nich sytuacji rodzinnej i partnersko-małżeńskiej wymaga dalszych oraz ciagle aktualizowanych badań. Inny wniosek płynący z przeprowadzonych badań to stwierdzenie, że duży odsetek respondentów żyje w kohabitacji. Jest to zjawisko zastanawiające zwłaszcza z uwagi na to, że występuje wśród praktykujących katolików. W tym przypadku wysoki poziom popularności dla kohabitacji potwierdzać może tezę, że religijność dziedziczona i kulturowa przeobraża się w kierunku religijności wyboru $^{33}$. Proces ten jest dla samej religii ambiwalentny. $Z$ jednej strony prowadzi do pogłębienia samoświadomości i osobistego zaangażowania w odkrywaniu religijnego kodu świata. Jednak z drugiej strony swoboda wyboru prowadzi do indywidualnej autokreacji religijności, która staje bardziej wybiórcza, synkretyczna, modalna i subiektywna. $\mathrm{Z}$ tej perspektywy powiązanie religijności i moralności rysuje się jako luźne i przygodne ${ }^{34}$.

\footnotetext{
${ }^{33}$ Por. I. B o r o w i k, T. D o k t ó r: Pluralizm religijny i moralny w Polsce. Kraków 2001.

${ }^{34}$ Por. M. O s s o w s k a: Socjologia moralności. Zarys zagadnień. Warszawa 2005 s. 79.
} 